\title{
PEMETAAN JARINGAN DISTRIBUSI (SUTM) 20 kV DAN PERKIRAAN KEBUTUHAN LISTRIK DI KECAMATAN PAYUNG SEKAKI, KABUPATEN SOLOK
}

\author{
Oleh : \\ Surfa Yondri *), Witrionanda *), Afadli *), Jefri Anakhi Nursalim**) \\ *)Staf Pengajar Jurusan Teknik Elektro Politeknik Negeri Padang \\ **)Mahasiswa Jurusan Teknik Elektro Politeknik Negeri Padang
}

\section{ABSTRACT}

Payung Sekaki district is one of the area in Solok Region that needs the development of electricity network. To support its development plan, the real condition of Payung Sekaki district should be known. The mapping method is one of the way to know the already implemented electricity area.Based on the mapping result, it is known that the electricity network of SUTM $20 \mathrm{kV}$ at Payung Sekaki district has been implemented in Sikrukam area and Supayang area and not yet in Aie Luo area. The estimation method of electricity needs at Payung Sekaki district is motivated to get information on its development based on economic and population growth. Data processing results using SPSS show that the eletricity needs at Payung Sekaki district from 2013 to 2014 will dramatically increase followed by the increasing of economic growth in spite of population growth is still remain the same.

Keywords : Network mapping, Electricity necessity estimation, SPSS

\section{PENDAHULUAN}

Kecamatan Payung Sekaki merupakan salah satu kecamatan di Kabupaten Solok yang saat ini masih dalam masa pengembangan oleh pemerintah daerah, salah satunya dari aspek ketenagalistrikan. Seiring dengan perkembangan perekonomian, pembangunan dan kependudukan, tentunya kebutuhan akan kelistrikan juga akan mengalami peningkatan dari tahun ketahun. Pemetaan terhadap jaringan distribusi merupakan salah satu langkah yang dapat dilakukan untuk mengetahui kondisi kelistrikan suatu daerah, dan hal seperti ini sebenarnya juga telah dilakukan oleh pihak PLN, hanya saja skalanya lebih besar, karena ditujukan untuk tingkat kabupaten atau propinsi
Oleh karena itu penulis tertarik untuk mencoba mendeskripsikan kondisi jaringan distribusi Saluran Udara Tegangan Menengah (SUTM) $20 \mathrm{kV}$ di Kecamatan Payung Sekaki dengan metode pemetaan jaringan di daerah tersebut melalui pancatatan titik kordinatnya menggunakan GPS dan pengaplikasian software pemetaan Arc view 3.3. Penulis berpendapat bahwa tulisan ini bisa bermanfaat untuk mendukung rencana pengembangan ketenagalistrikan di daerah ini, karena selain pemetaan, penulis juga melakukan perhitungan untuk memperkirakan kebutuhan listrik terkait dengan data kelistrikan dan data wilayah serta data dari Bapeda Kabupaten Solok, dan melalui metode perkiraan tersebut dapat di ketahui kebutuhan kelistrikan di 
Kecamatan Payung Sekaki untuk beberapa tahun ke depan.

\section{TUJUAN PENELITIAN}

Adapun tujuan dari penulisan laporan tugas akhir ini adalah sebagai berikut :

1. Untuk mendeskripsikan kondisi SUTM $20 \mathrm{kV}$ di Kecamatan Payung Sekaki, Kabupaten Solok melalui Pemetaan yang dilakukan,

2. Untuk memperkirakan kebutuhan listrik di kecamatan payung sekaki berdasarkan data kependudukan dan kelistrikan daerah.

\section{RUMUSAN MASALAH}

Berdasarkan latar belakang yang telah dikemukakan diatas maka dapat dirumuskan permasalahan sebagai berikut :

a. Bagaimana proses pemetaan jaringan distribusi kelistrikan untuk mendeskripsikan SUTM $20 \mathrm{kV}$ di Kecamatan Payung Sekaki, Kabupaten Solok?

b. Bagaimana pertumbuhan kebutuhan listrik di kecamatan payung sekaki berdasarkan data perkiraan kebutuhan listrik menggunakan SPSS.

\section{TINJAUAN PUSTAKA}

\section{Sistem Distribusi}

Sistem Distribusi merupakan bagian dari sistem tenaga listrik. Sistem distribusi ini berguna untuk menyalurkan tenaga listrik dari sumber daya listrik besar (Bulk Power Source) sampai ke konsumen, Jadi, fungsi distribusi tenaga Listrik adalah:

1) Pembagian atau penyaluran tenaga listrik ke beberapa tempat (pelanggan).
2) Merupakan sub sistem tenaga listrik yang langsung berhubungan dengan pelanggan, karena catu daya pada pusat-pusat beban (pelanggan) dilayani langsung melalui jaringan distribusi.

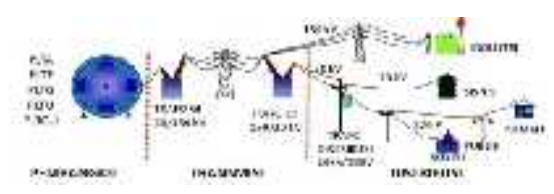

Gambar 1. Sistem pendistribusian listrik Sumber: :https://www.google.co $\mathrm{m} /$ search $? q=$ sistem + distribusi\&client

\section{Metode Pemetaan Jaringan Distribusi (SUTM) 20 kV}

Metode pemetaan merupakan metode yang difungsikan untuk mendeskripsikan secara visualisasi jaringan distribusi (Saluran Udara Tegangan Menegah) $20 \mathrm{kV}$ di kecamatan Payung Sekaki. Pada penulisan laporan ini digunakan software Arc View 3.3 untuk membuat peta jaringan distribusi yang dimaksud, dan untuk membuat peta jaringan tersebut dibutuhkan data berupa titik kordinat tiang-tiang SUTM $20 \mathrm{kV}$, yang mana data-data titik kordinat tiangtiang tersebut nantinya akan diproses menggunakan software Arc View 3.3.

Metode Perkiraan Kebutuhan Listrik

Perkiraan kebutuhan listrik diperlukan sebagai metode dalam pengembangan dan perencanaan terhadap kebutuhan kelistrikan suatu daerah dalam beberapa tahun ke depan. Dalam metode perkiraan kebutuhan listrik ini digunakan software SPSS sebagai aplikasi yang akan berfungsi sebagai pengolahan data-data pelanggan pada beberapa tahun kebelakang. Prakiraan kebutuhan listrik meliputi perkiraan beberapa jumlah pelanggan, dengan mengelompokkan pelanggan menjadi lima sektor yaitu : Sektor 
Rumah Tangga, Sektor Bisnis, Sektor Industri, Sektor Publik, Sektor Sosial

Perkiraan kebutuhan listrik berguna untuk mengetahui akan kebutuhan listrik di tahun yang akan datang. Hal ini dapat dilakukan dengan berbagai cara, salah satunya dengan metode SPSS. Metode ini merupakan metode menghitung perkiraan kebutuhan listrik tiap pelanggan dengan memperhitungkan jumlah pelanggan per sektor pelanggan, jumlah penduduk, jumlah Kepala Keluarga, dan PDRB pada wilayah tertentu.

\section{KONDISI WILAYAH}

\section{Keadaan Geografis}

Kecamatan Payung Sekaki merupakan bagian dari Kabupaten Solok yang terletak antara 0048 ' 36' dan 01 00' 00 " lintang selatan dan 100 46' 24" dan 100 58' 27' bujur timur. Topografi wilayah sangat bervariasi antara lembah dan berbukit-bukit dengan ketinggian antara 1026 - $1200 \mathrm{~m}$ di atas permukaan laut. Kecamatan Payung sekaki memiliki luas $364,5 \mathrm{~km}^{2}$ yang terdiri dari tiga nagari dan 11 Jorong, nagari dengan daerah terluas adalah nagari sirukam $133,4 \mathrm{~km}^{2}$ yang dibagi menjadi 4 Jorong dan juga merupakan Ibu Kota Kecamatan. Disusul kemudian dengan nagari Aie Luo dengan luas daerah sebesar $122 \mathrm{Km}$. Sedangkan luas daerah terkecil terdapat di nagari Supayang yang sama-sama memiliki 4 jorong, sedangkan nagari dengan jumlah jorong terkecil adalah nagari Aie Luo yang hanya memiliki tiga Jorong.

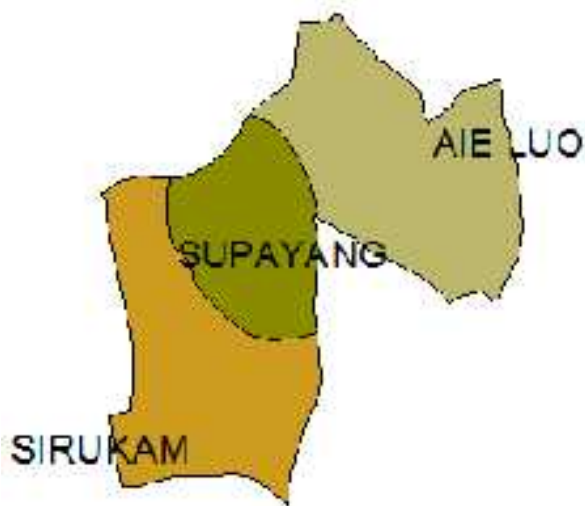

Gambar 3. Peta wilayah kecamatan Payung Sekaki

Sumber : file shp pada arc view

Tabel 1. Statistik geografi kecamatan payung sekaki

Sumber : Statistik Kecamatan Payung sekaki 2012 (BPS)

\begin{tabular}{|c|c|c|}
\hline Uraian & Satuan & Nilai \\
\hline Luas & Km2 & 364.5 \\
\hline $\begin{array}{c}\text { Jumlah hari } \\
\text { Hujan }\end{array}$ & Hari & 253 \\
\hline Jumlah Nagari & Nagari & 3 \\
\hline Jumlah Jorong & Jorong & 11 \\
\hline Ketinggian & M dpl & $1029-1200$ \\
\hline Jumlah Sungai & Buah & 2 \\
\hline Jumlah Danau & Buah & 0 \\
\hline Jumlah Pasar & Buah & 3 \\
\hline
\end{tabular}

\section{Kondisi kelistrikan}

Kecamatan payung sekaki dapat dikatakan masih kekurangan jaringan kelistrikan, terbukti berdasarkan hasil survey yang dilakukan masih ada desa yang belum mendapat pasokan listrik PLN terutama di nagari Aie Luo. Selain itu berdasarkan survey lapangan yang dilakukan pada daerah yang mendapat jaringan listrik $20 \mathrm{kV}$, ditemukan bahwa hanya terdapat 7 unit trafo penurun tegangan terpasang, dan itu artinya bahkan di daerah yang sudah mendapat jaringan listrik $20 \mathrm{kV}$ pun untuk ketersediaan jaringan listrik 220 volt masih sangat minim.

Kebutuhan listrik di kecamatan Payung Sekaki dikelola oleh PT.PLN (Persero) Ranting Kayu Aro, PLN Ranting Kayu aro melayani beberapa kecamatan yaitu : Gunung Talang, Lembah Gumanti, Hiliran Gumanti, Payung Sekaki, Lembang Jaya, bukit Sundi.

\section{Kondisi Pelanggan Listrik}

PT. PLN (Persero) Rayon Kayu Aro membagi kelompok pelanggan listrik menjadi 5 Jenis, oleh karena itu penulis melakukan survey di Kecamatan 
Payung Sekaki untuk mengetahui kondisi pelanggan listrik nya. Adapun kondisinya adalah sebagai berikut:

\section{Pelanggan Rumah Tangga}

Pelanggan Rumah Tangga merupakan pelanggan listrik yang menggunakan listrik untuk kebutuhan pribadi tiap-tiap rumah. Berikut foto kondisi pelanggan Rumah Tangga di Kecamatan Payung Sekaki.

2. Pelanggan Sosial

Pelanggan Sosial merupakan pelanggan listrik yang merupakan tempat untuk melakukan kegiatan yang bersifat social seperti sekolah, mesjid, dan lainya. Berikut foto kondisi pelanggan sosial di Kecamatan Payung Sekaki.

\section{Pelanggan Bisnis}

Pelanggan bisnis merupakan pelanggan listrik PLN untuk

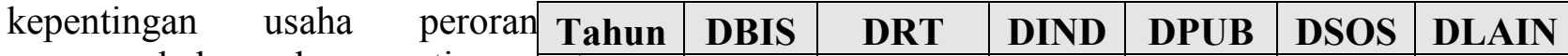
maupun kelompok, seperti warnet 2008 toko, bank, hotel, dan lainya.

4. Pelanggan Industri

Pelanggan industri merupakafi010 pelanggan listrik PLN ylang011 digunakan sebagai temp@012 menghasilkan sebuah produk sebagai produsen. Adapun contoh pelanggan industry adalah seperti pabrik.

\section{Pelanggan Publik}

Pelanggan publik adalah pelanggan listrik PLN yang merupakan tempat yang dibangun untuk keperluan public atau masyarakat umum. Adapun contoh pelanggan publik seperti, Kantor Camat dan Kantor Wali Nagari. Berikut salah satu foto kondisi pelanggan publik di Kecamatan Payung Sekaki.

\section{Data Pelanggan Listrik}

Berdasarkan survey data kelistrikan yang penulis lakukan di kecamatan Payung Sekaki, maka diperoleh data kelistrikan kecamatan Payung Sekaki sebagai berikut :

Tabel 2. Jumlah Pelanggan Listrik berdasarkan jenis pelanggan

\begin{tabular}{|c|c|c|cc|c|c|}
\hline Iahn & PRI & PS.S & PIND & PYLB & PLAIN & PSUS \\
\hline 2008 & 1457 & $4 C$ & $C$ & 6 & 7 & 46 \\
2009 & 1541 & 15 & 0 & 6 & 7 & 19 \\
\hline 2010 & 1625 & 51 & C & 6 & 7 & 51 \\
\hline 2011 & 1709 & 56 & C & 6 & 7 & 54 \\
\hline 2012 & 1793 & 62 & C & 6 & 8 & 56 \\
\hline
\end{tabular}

Keterangan :

PRT = Pelanggan Rumah Tangga

PBIS = Pelanggan Bisnis

PIND = Pelanggan Industri

PPUB $=$ Pelanggan Publik

PLAIN = Pelanggan Lain/layanan khusus

PSOS = Pelanggan Sosial

Tabel 3. Jumlah Daya Tersambung $(\mathrm{kVA})$ berdasarkan jenis pelanggan 


\begin{tabular}{|c|c|c|c|c|c|c|}
\hline & 6 & & & & & \\
\hline & 242 & & & & & \\
20 & 481 & 117 & & 135 & 103 & 763 \\
10 & 1 & 962 & 0 & 368 & 222 & 18 \\
\hline & 288 & & & & & \\
20 & 855 & 140 & & 161 & 122 & 909 \\
11 & 2 & 523 & 0 & 257 & 963 & 14 \\
\hline & 272 & & & & & \\
20 & 197 & 131 & & 146 & 115 & 881 \\
12 & 2 & 163 & 0 & 637 & 548 & 34 \\
\hline
\end{tabular}

Keterangan :

ERT $=$ Energi Rumah Tangga

EBIS $=$ Energi Bisnis

EIND $=$ Energi Industri

EPUB $=$ Energi Publik

ELAIN= Energi Lain/layanan khusus

ESOS = Energi Sosial

Tabel 5. Data penduduk, Rumah tangga, dan PDRB kecamatan Payung Sekaki

\begin{tabular}{|c|c|c|c|c|c|c|c|c|c|c|c|}
\hline ה. & midis & 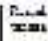 & {$[\mathrm{rex} / 2$} & ${ }_{n=14}$ & $\mathrm{rgs}_{\mathrm{S}}$ & $\mathrm{sca}_{4}$ & xihs: & בcha. & $\operatorname{sen}_{4}$ & $\operatorname{sog} x$ & Dows \\
\hline 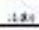 & $*+1$, & & $x$ ii & $\therefore$ & 1 & 40 & Bil & 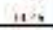 & 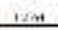 & $n$ & $\ldots$ \\
\hline$: x$ & $s$ & $v, z$ & $\Leftrightarrow \Leftrightarrow$ & $\Rightarrow$ & . & Fin & $\mu$ & 1.14 & $1, \infty$ & $\therefore$ & $\cdots$ \\
\hline 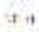 & $* H$ & $\rightarrow$ & $\pi$ & 4. & a & n & 153 & $\pi \cdot \omega$ & 18 & $\infty$ & 10.1 \\
\hline$m$ & $\mathrm{x}:$ & $x$ & $\mathrm{n \rightarrow T}$ & 35 & 1 & 697 & $17=$ & $35:$ & mile & $\because$ & 163 \\
\hline 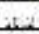 & $\mathrm{sux}$ & . & Gese & is & 1 & הan & Sبغ & 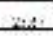 & S & لغس. & غنشف \\
\hline
\end{tabular}

Keterangan :

PDRTANI $=$ PDRB Pertanian

PDRTAM $=$ PDRB Pertambangan dan

Penggalian

PDRIND $=$ PDRB Industri Pengolahan

PDRLA = PDRB Listrik Dan Air bersih

PDRBANG $=$ PDRB Bangunan

PDRDAG $=$ PDRB Perdagangan, Hotel

dan Restoran

PDRANG $=$ PDRB Pengangkutan dan

Komunikasi

PDRKEU = PDRB Keuangan, jasa

Bangunan dan jasa perusahaan

PDRJASA = PDRB Jasa-jasa

\section{ANALISA HASIL SURVEI \\ Metode Pemetaan}

Proses pemetaan dilakukan dengan mensurvei semua jaringan Distribusi SUTM $20 \mathrm{kV}$ di kecamatan Payung Sekaki. Untuk memperoleh data yang akan diproses pada software pemetaan arc view, data yang dikumpulkan dalam bentuk titik koordinat yang dapat peroleh melalui pencatatan titik koordinat menggunakan GPS. Proses kegiatan pemetaan di tunjukan pada gambar berikut :
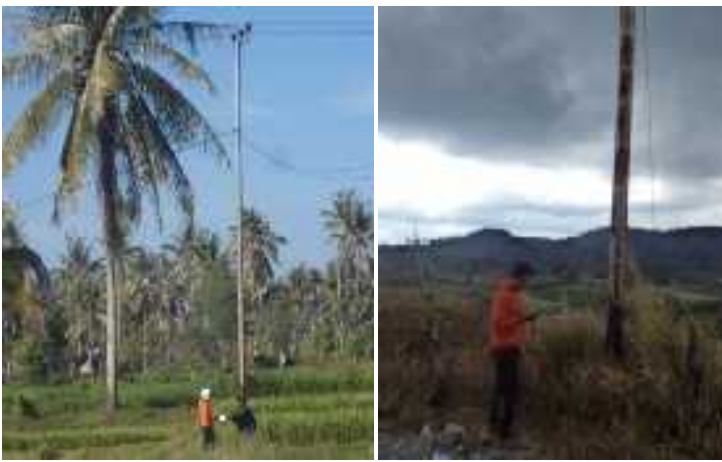

Gambar 4.1. Kegiatan pencatatan titik koordinat

Contoh hasil survey titik koordinat ditunjukan pada gambar 5 :

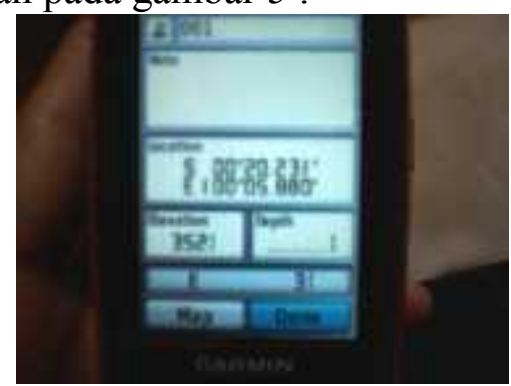

Gambar 5. Sampel Data koordinat pada GPS

Melalui kegiatan survey jaringan distribusi SUTM $20 \mathrm{kV}$ di kecamatan payung sekaki, diketahui bahwa jaringan distribusi hanya terdapat pada nagari sirukam dan nagari supayang, fakta ini diperoleh karena pada saat melakukan survey tiang-tiang saluran distribusi terhenti pada nagari supayang.

Panjang Jaringan kelistrikan Kecamatan Payung Sekaki saat ini yaitu $23 \mathrm{~km}$, dan jaringan ini meliputi semua daerah di Nagari Sirukam dan sebagian daerah di Nagari supayang, dan berdasarkan survey yang dilakukan oleh pihak dinas pertambangan dan energi di kecamatan Payung Sekaki, jarak dari batas jaringan SUTM yang berada di nagari Supayang dengan pemukiman penduduk terjauh di Nagari Aie Luo yang menjadi salah satu kawasan untuk 
perencanaan pengembangan jaringan yaitu sepanjang $14 \mathrm{~km}$.

Kondisi jaringan distribusi SUTM 20 kV di kecamatan payung sekaki dapat dilihat pada peta berikut ini :
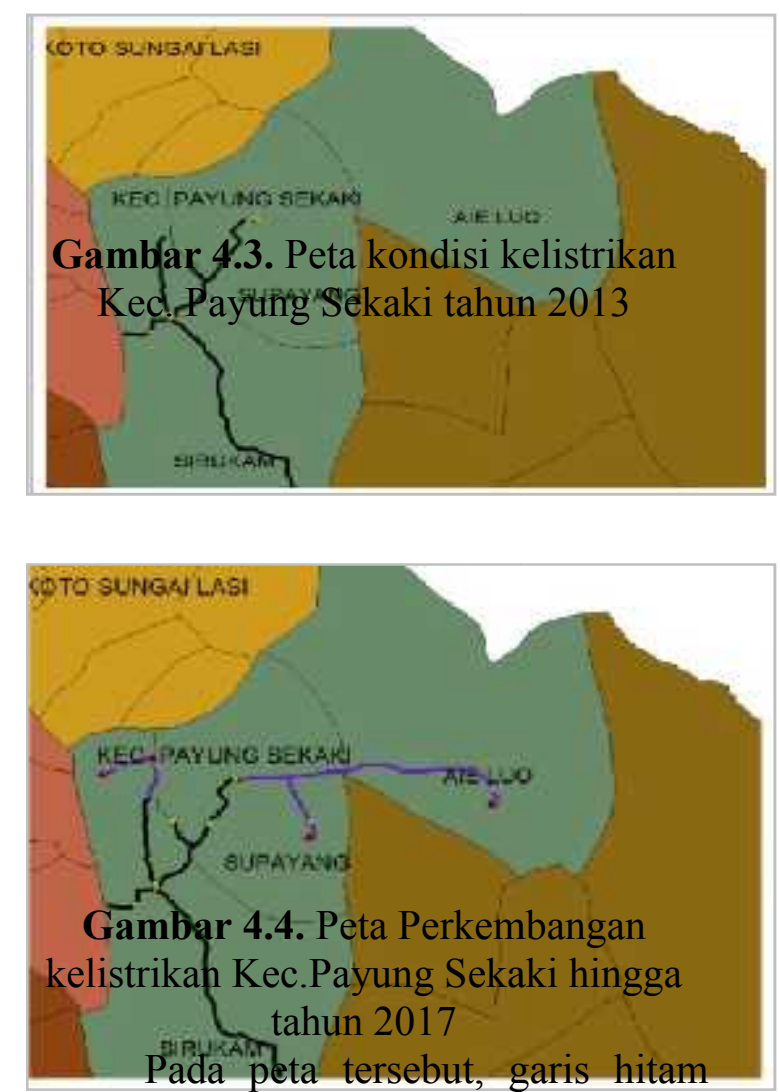

menunjukan tiang-tiang distribusi di Kecamatan Payung Sekaki, karena perbandingan skala pada peta dengan kondisi sesungguhnya membuat waypoint masing-masing tiang menjadi sangat rapat sehigga terlihat seperti garis, sedangkan titik kuning menunjukan waypoint semua trafo yang ada pada kecamatan payung sekaki. Dari peta tersebut dapat disimpulkan bahwa nagari aie luo sangat memerlukan penambahan jaringan distribusi dan trafo, sedang kan untuk nagari sirukam dan supayang meskipun telah mendapatkan jaringan SUTM, tetapi untuk trafo penurun tegangan masih minim dan masih perlu dilakukan penambahan agar kebutuhan akan kelistrikan di nagari tersebut dapat terpenuhi.
Pada peta perkiraan perkembangan Jaringan Listrik di Kecamatan Payung Sekaki, garis biru menunjukan perkiraan pengembangan jaringan listriknya dan titik abu-abu menunjukan perencanaan trafo nya. Sedangkan untuk symbol rumah menandakan kawasan pengembangan pemukiman penduduk yang direncanakan akan di aliri listrik nantinya.

\section{Analisa menggunakan SPSS}

Berdasarkan data-data yang telah penulis peroleh melalui hasil survey dan data Bapeda, maka penulis melakukan analisa dengan mengunakan SPSS, berdasarkan hasil pengolahan oleh SPSS diperoleh data perkiraan kebutuhan listrik di Kecamatan Payung Sekaki sebagai berikut :

Tabel 4.1. hasil forecast pelanggan listrik dari tahun 2013-2017

\begin{tabular}{c|cc|cc|cc}
\hline Tah_A & PRT & PSIS & =IND & PFUB & P-AN & PSOS \\
\hline 2013 & 1877 & 67 & 0 & 5 & 8 & 59 \\
\hline 2014 & 1951 & 73 & 0 & 5 & 8 & $\Xi 1$ \\
\hline 2015 & 2015 & 78 & 0 & 5 & 8 & 51 \\
\hline 2013 & 2229 & 84 & 0 & 5 & 8 & 56 \\
\hline 2011 & 2213 & 85 & 0 & 5 & $y$ & $5 y$ \\
\hline
\end{tabular}

\section{Pelanggan listrik}

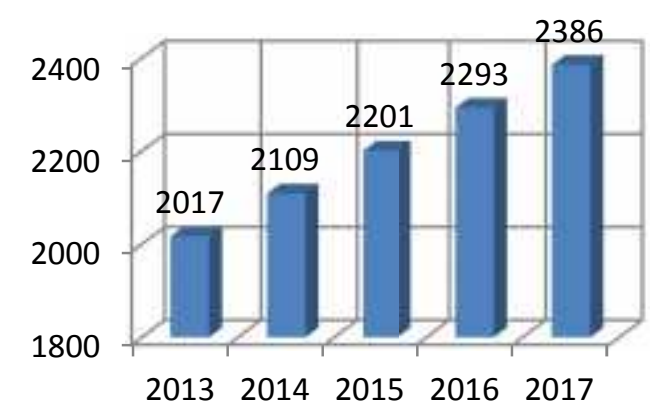

Gambar 4.5. Grafik pertumbuhan pelanggan listrik berdasarkan hasil forecast

Berikut persamaan yang digunakan dalam pengolahan data : PRT $=-167215+(84 *$ Tahun $)+(-$ $0.000000000001937 *$ PDRKEU $)+($ $-0.000000000003364 *$ R.tangga) 
PBIS $=-16797.933+(8.394 *$ Tahun $)+(-$ $14.195 *$ PDRKEU $)+(0.816 *$ PDRANG $)$ $\mathrm{PPUB}=8.058+(0.459 *$ PDRTAM $)+(0.00$ *R.tangga)

PLAIN $=8.9+(6.248 *$ PDRKEU $)+(0.82 * \mathrm{P}$

DRANG)

PSOS $=819.933+(14.195 *$ PDRKEU $)+(-$ 0.816*PDRANG)+(-0.394*Tahun)

Tabel 4.2. Hasil Forecast Daya tersambung (KVA) tahun 2013-2017

\begin{tabular}{|c|c|c|c|c|c|c|}
\hline Tahun & DBIS & DRT & DIND & DPUE & DSOS & DLAN \\
\hline 2013 & 70.3 & 1329.2 & 0 & 152.6 & 471 & 53.3 \\
\hline 2014 & 71.2 & 1547.0 & 0 & 155.2 & 47.7 & 54.1 \\
\hline 2015 & 72.1 & 1364.9 & 0 & 157.8 & 48.3 & 54.8 \\
\hline 2015 & 73.1 & 1382.7 & 0 & $2 C 0.4$ & 49.0 & 55.5 \\
\hline 2017 & 74.0 & 1400.5 & 0 & $2 C 3.0$ & 49.6 & 56.2 \\
\hline
\end{tabular}

\section{Daya tersambung}

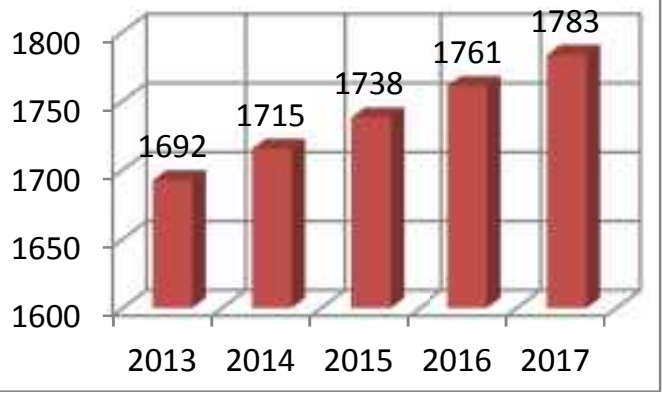

Gambar 4.6. Grafik perkiraan daya tersambung (kVA) tahun 2013-2017

Berikut persamaan yang digunakan :

DBIS $=-1834000+(9.781 *$ PDRKEU $)+$ (946.002*Tahun) $+(0.064 *$ PDRBANG $)$ $\mathrm{DRT}=-34590000+(-3.389 * \mathrm{PDRKEU})+$ (17843.618*Tahun)+(-

$0.554 *$ PDRBANG)

$\mathrm{DPUB}=2404000+(1209.689 *$ Tahun $)+(2$ 63.51*PDRTANI $+(902.761 *$ PDRDAG) DSOS $=$ -

$1234000+(3.389 *$ PDERKEU $)+$

(636.382*Tahun) $+(0.554 *$ PDRBANG)

DLAIN $=1394000+(0.000000000008949$

*PDERKEU)+ (719*Tahun) $+(0.000000000006799 *$ PDRBANG $)$

Tabel 4.3..Hasil Forecast konsumsi energi (kwh) tahun 2013-2017

\begin{tabular}{|c|c|c|c|c|c|c|}
\hline Totun & $\mathrm{ER}^{\top}$ & [DIS & CIND & IPUב & [SOS & IAIN \\
\hline 2013 & $32890 x 2$ & Isssy & o & $18=15$ & $1 / 10 \mathrm{~N} 2$ & 10styo \\
\hline 2014 & $351197 \%$ & 174984 & 0 & $199=81$ & $1557 \mathrm{rn}$ & $1159<2$ \\
\hline 2015 & 3934754 & 189819 & 0 & 217329 & 169319 & 127794 \\
\hline 2016 & $12 b / b x$ & $20>251$ & 0 & $2 s 50 b 6$ & 183738 & $1356^{\prime} 6$ \\
\hline 2011 & 1580151 & 220688 & $\mathrm{~J}$ & $\angle S 200$ & IU/ & 11 캐뇨 \\
\hline
\end{tabular}

\section{Konsumsi Energi}

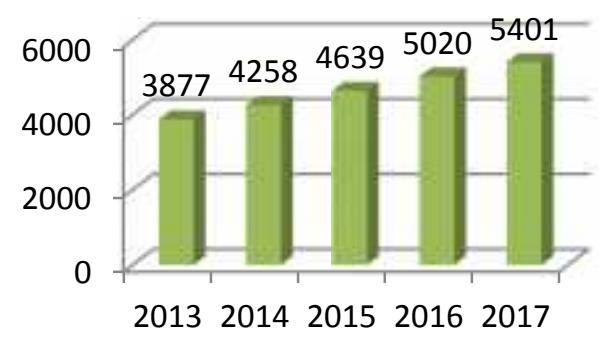

Gambar 4.7. Grafik perkiraan konsumsi energi (MWH) tahun 2013-2017

Berikut adalah persamaan yang digunakan :

- $\quad$ ERT $=3986000+(-$

2055.224*R.Tangga)+(162275.557*

PDRDAG)

- $\quad$ EBIS = 213972.459+(-

$115.442 *$ R.Tangga $)+(2622.895 * \mathrm{PD}$

RTANI)

- $\quad$ EPUB $=24098.409+(-$

5087.076*PDRTANI)+(21930.631*

PDRDAG)

- $\quad$ ESOS $=12171.63+(-$

3219.432*PDRTANI $)+(14854.502 *$

PADRDAG)

- $\quad$ ELAIN $=4510.1+(-$

1903.395*PDRTANI)+(9632.204*P

DRDAG)

\section{Neraca Energi Dan Neraca Daya}

Berdasarkan data perkiraan kebutuhan listrik Kecamatan Payung Sekaki dari tehun 2013-2017 dapat dibuat neraca Energi dan neraca Daya dari tahun 2013 sampai dengan tahun 2017. Neraca daya listrik ditunjukan pada table 4.4 dan Neraca energy listrik ditunjukan pada table 4.5.

a. Neraca Energi

Pada table 4.4, dapat dilihat bahwa produksi energi pada tahun 2012 (Existing) $\quad 3844.14 \quad$ MW, sedang 
konsumsi energy sebesar 3203.45 MW, berarti konsumsi energi pada tahun 2012 dalam keadaan surplus (Produksi energi lebih besar dari pada konsumsi energi). Berdasarkan perkiraan konsumsi energy dari tahun 2013 sampai tahun 2017 masih dalam keadaan surplus sehingga konsumsi energi di kecamatan payung sekaki dapat terpenuhi. karena kapasitas daya oleh pembangkit masih sangat besar dibandingkan beban puncak di kecamatan payung sekaki.

\section{b. Neraca daya}

Pada table 4.5 dapat dilihat bahwa kapasitas mampu pembangkit pada tahun 2012 masih sangat tinggi dibandingkan dengan beban puncak di kecamatan payung sekaki yaitu sebesar $477 \mathrm{MW}$, dan jika di persentasekan cadangan daya masih tersedia sebesar 99.85 \%. Berdasarkan perkiraan kebutuhan listrik di Kecamatan Payung Sekaki dari tahun 2013-2017 diperoleh kesimpulan bahwa kapasitas mampu pembangkit masih sanggup memenuhi kebutuhan beban puncak di kecamatan payung sekaki karena pada tahun 2017 cadangan daya masih sebanyak $99.73 \%$. Meskipun begitu kapasitas pembangkit tentunya akan terus mengalami penurunan kemampuan daya sedangkan kebutuhan akan daya listrik akan terus bertambah dari tahun ke tahun.

Neraca Daya dan Neraca Energi dapat dilihat pada tebel 4.4 dan 4.5 berikut :

Tabel 4.4 Neraca Energi Listrik Kecamatan Payung Sekaki Tahun 2013 -

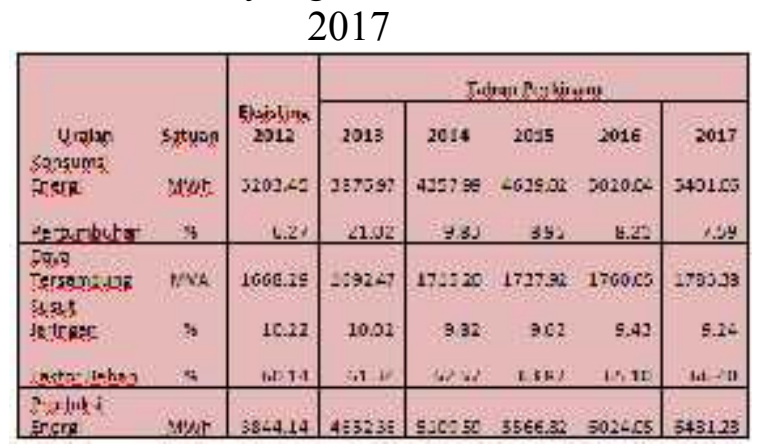

Tabel 4.5. Neraca Daya Listrik Kecamatan Payung Sekaki Tahun 2013-2017

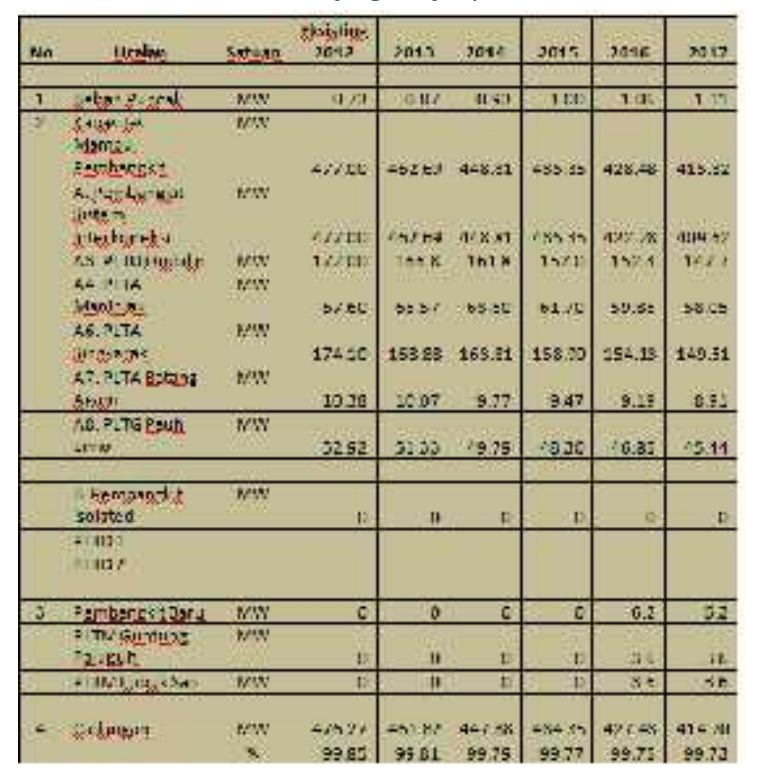

\section{KESIMPULAN}

Berdasarkan analisis dari hasil kegiatan survey dan pendataan yang dilakukan di kecamatan Payung Sekaki Kabupaten solok melalui proses pemetaan jaringan distribusi listrik dan perkiraan kebutuhan listrik di daerah tersebut, maka di peroleh kesimpulan sebagai berikut :

a. Metode regresi linear pada SPSS menghasilkan data perkiraan yang lebih akurat karena dapat menggunakan lebih dari satu variabel dalam pengolahannya dan variabel yang digunakan telah dicari nilai tingkat kecocokannya menggunakan metode korelasi.

b. Berdasarkan hasil Pemetaan, Aie Luo merupakan satu-satunya Nagari yang belum mendapat pasokan jaringan SUTM $20 \mathrm{kV}$, oleh karena itu dapat disimpulkan bahwa Nagari Aie Luo merupakan daerah yang paling membutuhkan pasokan listrik dari PLN.

c. Berdasarkan hasil persamaan yang diperoleh pada SPSS, peningkatan pelanggan listrik di Kecamatan Payung Sekaki dipengaruhi hampir oleh semua jenis PDRB, 
sedangkan untuk peningkatan kebutuhan daya tersambung dipengaruhi oleh PDRB di bidang pembangunan dan keuangan, dan pertumbuhan konsumsi energy dipengaruhi oleh PDRB di bidang Pertanian dan Perdagangan.

\section{DAFTAR PUSTAKA}

AS.Pabla. 1991, "Sistem Distribusi Daya Listrik”, Jakarta.

Billy, Mengolah Peta di ArcView Gis 3.3, (Online), (http://www.Mengolah Peta di ArcView Gis 3.3 Blognya punya Billy. BlogSpot. Com, diakses 28 juni 2013).

Dr.Hasanuddin Z.Abidin, Andrew Jones, Msc, Prof. Dr.Joenil Kahar. 2002, Survei Dengan GPS, Jakarta : PT Pradnya Paramita.

D. Stevenson JR William. 1981 , "Analisa Sistem Tenaga”, Malang,.

DR . A. Arismunandar, DR. S. Kuwahara. 1997, "Teknik Tenaga Listrik”, Volume Enam. Jakarta.

Eddy Prahasta, Ir., MT. 2004, Sistem Informasi Geografis : ArcView Lanjut, Malang : Informatika Bandung.

Ir. Budiarto, Info Program Komputer : SPSS, (Online), (http://www.Tentang SPSS Info Program Komputer, diakses 4 Juli 2013).

Badan perencanaan daerah Kabupaten Solok. 2013.

Dinas Pertambangan dan Energi Kabupaten Solok. 2013.

Badan Pusat Statistik Kabupaten Solok. 2008-2012. 